\title{
EL ORATORIO DE SAN FELIPE NERI Y LA CONTROVERSIA SOBRE LAS COMEDIAS EN LA VALENCIA DEL SIGLO XVII
}

\author{
POR \\ Emilio CALlado Estela \\ Universidad CEU Cardenal Herrera. Valencia
}

\section{RESUMEN}

El presente artículo analiza algunas de la implicaciones religiosas de la famosa controversia sobre la licitud o ilicitud del teatro, en el siglo XVII y en la ciudad de Valencia, a partir de un episodio protagonizado por don Luis Crespí de Borja, fundador del Oratorio de San Felipe Neri en tierras valencianas y consumado azote de las comedias, cuyo posicionamiento en este particular valdría a los oratorianos la persecución por parte de otros sectores eclesiásticos partidarios del arte escénico.

PALABRAS CLAVE: Teatro, controversia, siglo XVII, Valencia, Oratorio de San Felipe Neri, Don Luís Crespí de Borja

\section{THE ORATORY OF SAINT PHILIP NERI AND THE CONTROVERSY ABOUT COMEDY IN THE VALENCIA OF THE 17TH CENTURY}

\begin{abstract}
The present article analyzes some of the religious implications deriving from the famous controversy about the legality or illegality of theatre in the $17^{\text {th }}$ century and in the city of Valencia. The question arose from an episode in which Don Luis Crespi de Borja was directly implicated. Crespi was the founder of the Oratory of Saint Philip Neri in the Valencian region and a persistent fighter against comedy. As a consequence of his position in this affair members of the Oratory were pursued by other ecclesiastical sectors favouring theatre.
\end{abstract}

KEY WORDS: Theatre, controversy, $17^{\text {th }}$ century, Valencia, Oratory of Saint Philip Neri, Don Luis Crespi de Borja

Recibido/Received 13-01-2009

Aceptado/Accepted 13-10-2009 
A partir del Quinientos las representaciones escénicas en el ámbito hispánico, que salvo raras excepciones habían tenido siempre un carácter religioso, trataron de emanciparse encontrando tenaz oposición entre algunos teólogos y moralistas, quienes lograron en determinadas ocasiones y lugares, bajo la acusación de ilicitud, la prohibición de tales piezas por parte de la corona, el cierre de los corrales y aún la destrucción o cambio de destino de estos locales. ${ }^{1} \mathrm{Se}$ mejante polémica, prolongada con altibajos durante las posteriores centurias, tuvo especial resonancia en Valencia, con una intensa actividad teatral. ${ }^{2}$ Aquí, los pingües beneficios económicos derivados de la escena, animaron a los administradores del Hospital general a solicitar, como en tantas otras ciudades, que los dramas no pudieran representarse sino en el lugar por ellos señalado, muy pronto la casa de la Olivera; ${ }^{3}$ privilegio obtenido en 1582 , de la mano del virrey don Francisco de Moncada, conde de Aitona, y ratificado por Felipe II, a propuesta de los brazos militar, real y eclesiástico, en las cortes celebradas en la localidad aragonesa de Monzón tres años después. ${ }^{4}$

Indispensables desde entonces las rentas proporcionadas por el teatro para el sostenimiento de la primera institución sanitaria de la capital valentina, sus arcas padecerían dramáticamente durante los períodos de inactividad comediógrafa prescrita en las décadas siguientes por las autoridades con motivo de calamidades públicas, particularmente la devastadora epidemia pestífera que entre 1647 y 1648 había asolado la ciudad; las andanadas de un bandolerismo endémico, recrudecido en los últimos tiempos; o cualquier luto, como el decretado en 1644 tras el fallecimiento de la reina Isabel, seguido meses más tarde

${ }^{1}$ E. Cotarelo Mori, Bibliografía de las controversias sobre la licitud del teatro en España, Madrid, 1904. Existe una nueva edición de esta obra clásica, con estudio preliminar e índices de J. L. SUÁREZ GARCÍA, publicada en 1997 por la Universidad de Granada.

${ }^{2}$ Entre otros, son fundamentales a este respecto los trabajos de L. LAMARCA, El teatro en Valencia: desde su origen hasta nuestros días, Valencia, 1840; H. MÉRIMÉE, Spectacles et comediens a Valencia (1580-1630), Toulouse, 1913, y El arte dramático en Valencia, Valencia, 1985, 2 vols.; E. JuLiÁ MARTÍNEZ, «El teatro en Valencia», Boletín de la Real Academia Española, II (1915), IV (1917) y XIII (1926) 527-547, 56-83 y 318-341, respectivamente; V. ESQUERDO, «Aportación al estudio del teatro en Valencia durante el siglo XVII: actores que representaron y su contratación por el Hospital general», Boletín de la Real Academia Española, LV (1975), 429-530; J. MouYEN, «Las casas de comedias de Valencia», Cuadernos de Teatro clásico, 6 (1991), pp. 91-122; y P. SARRIó RuBIO, La vida teatral valenciana en el siglo XVII, Valencia, 2001.

${ }^{3}$ M. VILAR Devís, El Hospital general en la Valencia foral moderna (1600-1700), Valencia, 1996, p. 93.

${ }^{4}$ El fuero en cuestión diría así «Que lo privilegi de la Casa de les farces sia confirmat y de nou otorgat al Hospital general de la ciutat de València. Item, que vostra magestat sia servit confirmar y de nou otorgar lo privilegi concedit per lo llochtinent general de vostra magestat al dit Hospital general, circa la casa de les farces, iuxta lo seie y tenor del dit privilegi. Plau a sa magestat». Furs, Felipe II, 1585 , cap. CII, f. $15 \mathrm{v}$.

Hispania Sacra, LXIII

127, enero-junio 2011, 133-153, ISSN: 0018-215-X 
por la desaparición del príncipe Baltasar Carlos..$^{5}$ Únicamente las segundas nupcias de Felipe IV con doña Mariana de Austria, a finales de los años cuarenta, supusieron un alivio en «tiempos tan vidriosos», según expresión del entonces lugarteniente general del reino don Eduardo Fernández Âlvarez de Toledo, conde de Oropesa; respiro aprovechado para reclamar la reanudación de estos espectáculos. En tal sentido, los responsables del Hospital trataron de dar fuerza a sus reivindicaciones mediante la convocatoria de una junta eclesiástica de teólogos, catedráticos y calificadores del Santo Oficio, para la cual fue reclutado un consumado azote de las comedias, el fundador del Oratorio de San Felipe Neri en tierras valencianas don Luis Crespí de Borja. ${ }^{6}$

\section{LA CONGREGACIÓN DE LOS CRISPPIANOS}

Nacido en Valencia de noble familia, ${ }^{7}$ allá por 1607, don Luis Crespí se había formado en el Estudi General de su ciudad natal, donde obtuvo el bachiller en Artes y Teología, doctorándose poco después en esta última disciplina. ${ }^{8}$ En 1629 ganaba una cátedra pavordía de Teología Escolástica que compaginaría tras su ordenación sacerdotal con el ministerio del altar. Cuatro años llevaba en ello cuando el destino le condujo hasta la Santa Sede para hacer valer exitosamente los derechos de los pavordes en su viejo pleito con los canónigos de la seo, a quienes disputaban protagonismo en la iglesia mayor. ${ }^{9}$

Allí en Roma entraría en contacto con el Oratorio de San Felipe Neri, congregación clerical de derecho pontificio, sin votos, fundada en 1575 y confir-

\footnotetext{
${ }^{5}$ Para el estudio de aquellos aciagos años vividos en la capital del Turia, véase S. LA PARRA, Peste $y$ crisis política en Valencia (1647-1648). Tesis de Licenciatura inédita. Universitat de València, s.a.; S. GARCÍA MARTíNEZ, Valencia bajo Carlos II. Bandolerismo, reivindicaciones agrarias y servicios a la monarquía, Valencia, 1991; A. FELIPO ORTS, Insaculación y élites de poder en la ciudad de Valencia, 1996; y E. CALLADO Estela, Iglesia, poder y sociedad en el siglo XVII. El arzobispo de Valencia fray Isidoro Aliaga, Valencia, 2001.

${ }^{6}$ T. ReSURRECCIÓN SABOya, Vida del venerable y apostólico prelado, el ilustríssimo y excelentíssimo señor don Luis Crespí de Borja, obispo que fue de Orihuela y Plasencia y embaxador extraordinario por la magestad católica del rey Felipe IV a la santidad de Alexandro VII para la declaración del culto de la Concepción de María, felizmente conseguida, Valencia, 1676.

${ }^{7}$ Sobre los orígenes y avatares de tan ilustre linaje resultan imprescindibles los siguientes trabajos: V. Pons Alós, El señorío de Sumacàrcer en la Baja Edad Media. De mudéjares a moriscos, Sumacàrcer, 1995, y V. Pons Pons, El señorío de Sumacàrcer en el siglo XVII: la expulsión de los moriscos y la repoblación cristiana, Sumacàrcer, 1999.

${ }^{8}$ A. Felipo OrTs, La Universidad de Valencia durante el siglo XVII (1611-1707), Valencia, 1991, p. 318.

${ }^{9}$ Fruto de aquellas diligencias serían las páginas escritas por el propio Crespí con el título Origen y progresso de las pabordrías de la sancta metropolitana iglesia de Valencia, por Silvio Ciprés de Pobar, Roma,1641.
} 
mada veintisiete años después por el papa Paulo V con la bula Christi fidelium..$^{10}$ El pavorde frecuentó con asiduidad Santa María de la Vallicella, casa madre de los filipenses, deslumbrado por la religiosidad de estos sacerdotes seculares que habían iniciado su vida en común en torno al desaparecido san Felipe, para practicar la música, la caridad, y sobre todo la predicación. Logró entablar «muy estrecha amistad con los presbyteros de aquella comunidad santa -encabezados por el prepósito Pietro Giacomo Bacci, discípulo directo del fundador-tratando y comunicando con ellos como si fuera compañero y hermano suyo». Su regreso a Valencia le impidió por el momento formalizar su incorporación a los oratorianos, permitiéndole, sin embargo, intimar con un elitista grupo de clérigos, con importante presencia en el ámbito universitario y en determinados cargos eclesiásticos, integrado por don Felipe Pesantes y Boïl, el arcediano de Xàtiva don Francisco Sorell, hermano del conde de Albalat, y el canónigo don Juan García, quienes llevaban algún tiempo detrás de fundar una congregación en la capital del Turia al estilo de la Vallicella romana. ${ }^{11}$

Los cuatro trastearon el asunto durante meses para darle mayor concreción, hasta que la beligerancia capitular con la sentencia pontificia favorable a la pavordía obligó a don Luis a posponer sus planes fundacionales para comparecer de nuevo ante la curia romana, que en 1641 volvía a dar la razón a sus representados. Premiado con el arcedianato de Morvedre, una de las dignidades de mayor rango de la catedral valentina, el pavorde puso rumbo a casa unos meses más tarde, «tan diestro y consumado en los exercicios que no sólamente havía visto sino también practicado en el Oratorio de Roma, que podía con justíssima título gloriarse de congregante de aquella corte insigne, porque aunque no havía entrado en su gremio era tan continuo en ellos y en el trato familiar con los padres de aquella congregación sagrada, que sin duda parecía parte de aquella evangélica familia». Como tal se presentaría ante su círculo de amigos, ampliado en lo sucesivo con la adhesión de personajes de la talla de don Luis Escrivá y Zapata, don Juan Jerónimo Vivas y Vic, ${ }^{12}$ José de Miranda y los doc-

${ }^{10}$ En relación a este particular, véase la monumental obra de J. MARCIANO, Memorias históricas de la Congregación del Oratorio, Madrid, 1854. Su volumen V, dedicado a Valencia, es una reproducción casi literal de las noticias proporcionadas al respecto por la biografía del padre Tomás de la Resurrección arriba citada, que seguiremos al pie de la letra de no indicarse lo contrario.

${ }^{11}$ Y junto a ellos, el ya fallecido don Miguel de Cervelló. A. FeLIPO ORTS, «La espiritualidad de don Miguel y don Gerardo de Cervelló. Entre el Oratorio de San Felipe Neri y la Escuela de Cristo de Valencia», Saitabi, 58 ( 2008 ), pp. 97-208.

${ }^{12}$ Señor de los mayorazgos de sus apellidos, don Juan Jerónimo había optado desde joven por la vida eclesiástica, mudando su vocación inicial de franciscano descalzo por el Oratorio. No obstante ello, obtuvo un breve de la Santa Sede autorizándole a vivir fuera de la comunidad filipense una vez erigida ésta, fundando junto al convento de Jerusalem un pequeño seminario, «con las calidades que prescrive el concilio Tridentino», regido por constituciones propias y financiado de su propio bolsillo. V. XIMENO, Escritores del reyno de Valencia chronológicamente ordenados desde el año MCCXXXVIII de la christiana conquista de la misma ciudad hasta el de MDCCXLVIII, Valencia, 1749, vol. II, pp. $42-43$.

Hispania Sacra, LXIII

127, enero-junio 2011, 133-153, ISSN: 0018-215-X 
tores Diego de Liñán, Juan Jerónimo Pertusa, Gaspar Tahuenga ${ }^{13}$ y Antonio Buenaventura Guerau ${ }^{14}$ o Felipe Bresa, ${ }^{15}$ para retomar entre todos la idea de levantar en el cap i casal la primera comunidad filipense de la Monarquía.

Las cantidades recaudadas y el visto bueno de la corona no evitaron que el proyecto quedara empantanado durante algún tiempo debido a las reticencias de determinados sectores eclesiásticos, concretamente los dominicos y el entonces arzobispo de Valencia, el también dominico fray Isidoro Aliaga. Para la orden de Predicadores, el establecimiento de una nueva fundación tan diferente al modelo religioso tradicional por ella representada no tenía cabida en una ciudad bien servida ya espiritualmente por las catorce iglesias parroquiales existentes; una decena larga de conventos; varios colegios eclesiásticos; las casas de cuatro órdenes militares, más las del Santo Oficio; infinidad de capillas gremiales, cofradías, etcétera; instituciones todas ellas, en mayor o menor medida, víctimas del caos económico acarreado para el reino entero por la diáspora morisca, que a más de una había llevado a la ruina. ${ }^{16}$

Así las cosas, Crespí hubo de negociar personalmente con el prelado para convencerle de la viabilidad del Oratorio, cuyas bondades le expondría detalladamente en varias audiencias privadas. El padre Aliaga acabó transigiendo, bien por las gestiones de don Luis, bien por la intercesión de uno de sus dos hermanos mayores fray Francisco, prior del convento de Predicadores de Valencia y hombre de gran prestigio entre los frailes blanquinegros. ${ }^{17}$ Cualquiera

\footnotetext{
${ }^{13}$ Natural de Castelló de Xàtiva y compañero de cátedra de don Luis Crespí, había estudiado en la Universidad de Valencia, donde obtuvo una cátedra de Teología. En aquellas mismas aulas creó escuela entre algunos alumnos que con el tiempo pasarían a formar parte también del Oratorio, como Gaspar Blas Arbuixec o Francisco Climent. Ibidem, pp. 88-89.

${ }^{14}$ Era éste tenido por «varón docto y religioso» cuyo dominio de la palabra y conocimiento de las Sagradas Escrituras le habían convertido en un asiduo del púlpito, hasta el punto de nombrarle la Ciudad de Valencia predicador oficial. Testimonio de tan prolífica actividad predicadora serían su Sermó en la festa del segon centenari de la canonizació del pare sanct Vicent Ferrer, Valencia, 1654, Sermó a les noves de la canonizació de sanct Thomàs de Vilanova, Valencia, 1659, Oración fúnebre a la muerte del rey nuestro señor Felipe IV el Grande, Valencia, 1666 y Sermó en les exèquies del reverent frare Pere Esteve, predicador apostòlic y comissari de la Casa Santa de Jerusalem, Valencia, 1677. Ibidem, pp. 42-44.

${ }^{15}$ Alumno de don Luis en las aulas del Estudi General, gozó de un beneficio eclesiástico en la catedral de Valencia, regentado hasta su temprana muerte acaecida en 1662 con apenas treinta y cuatro años. Tuvo tiempo de loar a su maestro con motivo de la declaración inmaculista de Alejandro VII, en Doce nuevas estrellas con que la santidad de nuestro beatíssimo padre Alexandro VII esmalta la corona de la Inmaculada Concepción de María Santíssima, en doce diferencias y ventajas que expressa en su bula a favor de la sentencia pía a más de las que le dan los sumos pontífices sus antecessores, Valencia, 1662. Ibidem, p. 29.

16 M. SAnchis GUARner, La ciutat de València. Síntesi de Geografia i Història urbana, Valencia, 1983, pp. 318

17 De este de quien las crónicas de la orden dominicana apuntaron ser tan opuesto a su hermano «en la opinión y en el genio, como en la vocación y en el hábito», ya hablamos en E. CALLADo EsTELA,
} 
que fuese el caso, en 1645 la mitra concedía licencia provisional a la Congregación de Crespí o los crispianos, como empezaba a conocérseles, para iniciar algunas de sus prácticas todos los miércoles y domingos, en la iglesia de San Juan del Hospital, con un par de pláticas espirituales a la espera de comprobar sus resultados para otorgarles autorización definitiva. Lo que no ocurrió hasta un año después, comenzando entonces la vida en comunidad en unas dependencias colindantes al citado templo. El fallecimiento del arzobispo, y la consiguiente declaración de la sede vacante, dieron vía libre a don Luis para buscar terrenos en los que levantar templo propio. Instalaciones ubicadas al final sobre la antigua casa de comedias de los Santets, próximas a la calle del Mar, e inauguradas a punto de concluir 1648 .

Prometíaselas felices el Oratorio cuando se desató contra él una campaña de acoso y derribo lacónicamente insinuada por el biógrafo oficial de su fundador en Valencia

«...quiso la Magestad Divina hazerla en los principios espejo de mansedumbre, exemplo de sufrimiento y dechado vivo de mortificación y paciencia, permitiendo que estos apóstoles sacerdotes padeciessen algunas persecuciones de muchas personas... Esparcióse el rigor contra ellos, no solamente en los pechos de la gente vulgar, que sirve de hazer bulto y montón en la república, sino en los de algunas personas de suposición y autoridad en ella. Y unos, incitados del Demonio, por ser aquella santa comunidad tan contraria en sus saludables exercicios a sus depravados intentos, y otros, atribuyendo a novedad impertinente tan soberanos misterios, por mirarlo con el antojo de la liviandad y esparcimiento, començaron con las saetas de sus lenguas a herir cruelmente a estos evangélicos varones». ${ }^{18}$

Poco se conoce de aquella persecución. Sólo que la participación de Crespí y sus crispianos en la agria controversia sobre la licitud de las comedias, ventilada entonces por todos los rincones de la Monarquía, brindaría una excusa para su hostigamiento por parte de los estamentos eclesiásticos amenazados por la creciente popularidad de esta comunidad, cuyo modelo de espiritualidad, basado en la aceptación de las experiencias místicas, la divulgación de las mismas entre amplios segmentos de la sociedad y la participación de las mujeres, ya fueran, casadas, beatas o monjas, fue puesto en entredicho. ${ }^{19}$ Un nuevo episodio de las rivalidades intestinas del clero valentino por el liderazgo religioso de la capital estaba pues servido.

\footnotetext{
«Dominico, prior y obispo. Apuntes para una biografía de fray Francisco Crespí de Valldaura (16021662)», Anales Valentinos, 66 (2007), pp. 305-319.

${ }_{18}^{18}$ T. ResurReCCión Saboya, Vida del venerable y apostólico prelado..., p. 104.

${ }^{19}$ F. PONS Fuster, «Monjas y beatas. Mujeres en la espiritualidad valenciana de los siglos XVI y XVII», en E. CALlado Estela (coord.), Valencianos en la Historia de la Iglesia II, Valencia, 2008, pp. 241-242.
} 


\section{LA JUNTA DE 1649}

Don Luis Crespí de Borja no era desde luego un enamorado de las comedias, contra cuya representación se había declarado públicamente en reiteradas ocasiones. Así lo constatan al menos los cronistas dominicanos coetáneos, alineados con la tesis oficial de la orden de Predicadores en materia teatral, conforme a la cual, según había sentenciado santo Tomás de Aquino, no era intrínsicamente malo tan cuestionado espectáculo -siempre y cuando no incurriera en deshonestidades tales que lo convirtieran en pecaminoso- sino indiferente y útil para el bien común de la sociedad, a la que podía proporcionar alivio frente al trabajo y los sinsabores vitales. ${ }^{20}$ En concreto, el conocido fray Tomás Güell escribiría que era habitual en el pavorde

«...condenar a pecado mortal el assistir a las comedias, de lo qual hazía assumpto principal en el púlpito y era muy freqüente en ponderarlo. Y no pocas vezes zaería, aún a los primeros hombres en literatura de Valencia, a los que defendian ser obra indiferente y de suyo no pecaminosa assistir a las comedias que los comediantes representan en la casa pública para esta diversión destinada».21

Efectivamente, la más sonada de estas intervenciones había tenido lugar en 1646 con motivo de un sermón predicado por don Luis en la catedral.22 Articulado en varias partes, la primera de ellas daría cuenta de los orígenes de estas piezas teatrales entre los cristianos, que de pías y edificantes habían acabado corrompiéndose con «la livianidad de las acciones, la descompostura de los trages, la insolencia de las mugeres, la deshonestidad de las palabras, la disolución de los bailes y entremeses, lo lascivo de los amores...».23

Era pecado mortal, pues, como sostendría el pavorde en una segunda parte de su alocución -apoyándose en los Santos Padres y autoridades más contemporáneas como fray José de Jesús María, fray Pedro de Guzmán, fray Antonio de Arce, fray Alonso de Ribera o fray Juan de Santo Tomás- componer tales obras, fueran sus autores seglares, o peor todavía eclesiásticos, en referencia clara a Lope de Vega, porque «no sólo a personas fáciles y ya inclinadas, si no ya a las muy fuertes y castas, han pervertido y hecho caer en flaquezas de sensualidad y deleites». ${ }^{24}$ Pecaban también los actores al hacer «delante de otros

${ }^{20}$ R. M. DE Hornedo, «Teatro e Iglesia en los siglos XVII y XVIII», en R. García-Villoslada (Dir.), Historia de la Iglesia en España IV. La Iglesia en la España de los siglos XVII y XVIII, Madrid, 1979, particularmente pp. 326-327.

${ }^{21}$ BUV. Ms. 13, T. Güell, Noticias varias, sp.

22 Contenido en L. CRESPí DE BORJA, Respuesta a una consulta sobre si son lícitas las comedias que se usan en España, Valencia, 1649.

23 Ibidem, p. 11.

24 Ibidem, p. 18. 
cosas que son pecado, aunque ellos no se deleiten»; y no menos los responsables políticos que las permitían, por mucho que procuraran fundar su temeridad en la evitación de males peores; primero, y así ocurría en Roma, Génova o Venecia, porque «quando no ay comedias, o donde no las ay, no ay mayores pecados, luego las comedias no los evitan»; segundo, porque "quando ay comedias, o donde las ay, no menguan los pecados», bastando para comprobarlo los casos de Segorbe, Xàtiva o la propia Valencia; y tercero, porque «quando o donde ay comedias torpes, crecen los pecados», en las mismas representaciones y fuera de ellas. ${ }^{25}$ Pecadores, igualmente, eran quienes contrataban a los comediantes, por cuanto «nadie puede pagar, rogar, instar y aconsejar a uno que haga una acción torpe», ni siquiera en beneficio de terceros, llamáranse éstos pobres o enfermos hospitalizados. ${ }^{26}$ Pecado compartido, del mismo modo, por los espectadores, tanto aquellos más débiles que acudían al espectáculo con «moral peligro de caída», como los que concurrían sin el mismo, por ser «cosa verdaderamente dificil estar junto al fuego y no sentir el calor».27

Para finalizar, Crespí dedicaría la tercera parte de su homilía a rebatir las tesis más comunes sostenidas por los defensores de las comedias, en particular la que insistía en su permisión por parte de las autoridades, ya para la escenificación, ya para la posterior impresión, como prueba irrefutable de su moralidad, argumento poco madurado en palabras del pavorde, "porque las rameras se permiten y no por esso es lícito tratar con ellas (y) lo mismo es de la casa pública», y falso, además, en el caso valenciano, porque «en los tiempos de san Vicente Ferrer y del beato Tomás de Villanueva no eran permitidas las comedias, sino de la misma manera que ahora, caluniándolas los santos...». ${ }^{28}$

Tres años habían pasado desde aquel sermón cuando don Luis fue llamado a participar en la junta de expertos reunida por los administradores del Hospital general de Valencia, el 26 de agosto de 1649, para tratar de dilucidar, con vistas a sus reivindicaciones ante el monarca, la licitud o ilicitud de las comedias. A la junta asistieron «las personas más graves y doctas de la ciudad», entre ellas dos hombres muy cercanos a Crespí, su hermano fray Francisco y su mentor fray Pedro Olginat de Médicis, futuros obispos de Vic y Orihuela, respectivamente. De momento, el primero, acababa de abandonar el priorato del convento de Predicadores de Valencia para convertirse en Provincial de la orden blanquinegra para toda la Corona de Aragón. Provincial también de los territorios catalanoaragoneses, pero para el Carmelo, el padre Olginat había regentado una cátedra de Metafísica en el Estudi General valentino, donde tuvo como discípu-

\footnotetext{
25 Ibidem, pp. 26-33.

${ }^{26}$ Ibidem, p. 35.

${ }^{27}$ Ibidem, pp. 37-39.

${ }^{28}$ Ibidem, pp. 50-51.
}

Hispania Sacra, LXIII

127, enero-junio 2011, 133-153, ISSN: 0018-215-X 
lo a nuestro protagonista, dirigiendo asimismo, durante algún tiempo, el principal establecimiento de su orden en la capital del Turia. ${ }^{29}$

Completaban la nómina de convocados los padres dominicos Acacio March de Velasco, actual prior del convento de Predicadores de Valencia, doctor en Teología, catedrático de Filosofía Moral, definidor y vicario general de la Provincia de Aragón más tarde promovido a la mitra oriolana;30 Juan Bautista Polo, del mismo cenobio, catedrático jubilado de Artes y Teología; ${ }^{11}$ Gaspar Catalá de Monsonís, maestro en Sagrada Teología, superior del convento de San Onofre y en breve obispo electo de Lleida;32 y fray Mateo Baeza. Acompañaban a éstos los definidores de la Provincia de san Francisco, fray Lorenzo Guardiola y fray Francisco Sanz, y sus hermanos de hábito fray Francisco Fernández y fray Jaime Morales de Duarte. Los mercedarios estarían representados por fray Tomás Ramón, Provincial de Aragón, y su predecesor en el cargo fray Antonio Gralla, examinador sinodal diocesano y calificador del Santo Oficio. ${ }^{33}$ Y junto a ellos, el padre Marco Antonio Alós y Orraca, prolífico escritor de la Santísima Trinidad más conocido por el sobrenombre de Ter maximus; ${ }^{34}$ el capuchino fray Andrés de Valencia; el padre prior del convento valentino del Carmen Anastasio Vives de Rocamora, en tan sólo unos años Provincial de su religión y algo más tarde obispo de Segorbe; ${ }^{35}$ el teólogo agustino fray Mateo Moliner, catedrático de Sentencias del Estudi general;36 el padre Jerónimo Vilar, de la Compañía de Jesús; don Juan de los Herreros, prior de Montalbán; los catedráticos pavordes Victoriano Valda, de Cánones, ${ }^{37}$ y de Teología, Jerónimo Trilles $^{38}$ y Melchor Fuster, este último, al tiempo, vicecanciller de la Universidad de Valencia, síndico del brazo eclesiástico y contador de la Diputación del reino;39 el doctor Jimeno Pérez Argent de Calatayud, canónigo de la catedral y calificador inquisitorial;40 los beneficiados de la seo Juan Bautista Colomer y Martín Guillermo Villorado; Pedro Mercer de Tarragona, capellán del Hospital general; y el párroco de San Martín José Do, examinador sinodal.

${ }^{29}$ V. XiMENo, Escritores del reyno de Valencia ..., vol. II, pp. 20-21.

${ }^{30}$ G. Vidal Tur, Un obispado español: el de Orihuela-Alicante, Alicante, 1961, vol. I, pp. 256260 .

${ }^{31}$ V. XIMENo, Escritores del reyno de Valencia..., vol. II, pp. 45-46.

32 Ibidem, pp. 3-4.

33 Ibidem, p. 23.

${ }^{34}$ Ibidem, pp. 46-47.

${ }^{35}$ F. VILlagrasa, Antigüedad de la iglesia catedral de Segorbe y catálogo de sus obispos, Valencia, 1664 , p. 250.

${ }^{36}$ A. FELIPO ORTS, La Universidad de Valencia..., p. 335.

37 Ibidem, p. 389.

38 Ibidem, p. 387.

${ }^{39}$ V. Ximeno, Escritores del reyno de Valencia..., vol. II, pp. 99-102.

40 J. AIERDI, Noticies de València i son regne, de 1661 a 1664 i de 1667 a 1679. A cura de V. J. Escartí, Barcelona, 1999, p. 201. 
Las posibles discrepancias entre los citados ante la consulta planteada por los administradores no quedaron recogidas en su veredicto final, firmado de puño y letra por todos ellos, con la excepción del jesuita padre Vilar, consecuente con la postura oficial de la Compañía, contraria al teatro ${ }^{41}$ y opuesto por tanto a un fallo favorable a los intereses del Hospital, cuya extraordinaria labor asistencial durante la reciente epidemia de peste se vería así recompensada. ${ }^{42}$ La junta dictaminaba

"1. Que las comedias, de suyo, son actos indiferentes, y que el assistir a ella y oírlas puede ser acto de virtud de eutropelía, y por consiguiente de acto libre de pecado.

2. Que las comedias, si no hay cosas muy torpes y muy provocativas a sensualidad en ellas, son lícitas, tanto el representarlas como el oírlas; y si las huviere, no.

3. Que los representantes, por llevar esta professión y vida, si no representan comedias muy torpes ni el modo fuere muy torpe, no están en pecado mortal, pues los prelados y padres de la Iglesia los admiten a comunión y confessión sacramental, lo que no pudieran hazer si su professión fuera de pecado mortal.

4. Que siendo las comedias que han de usarse en España ut in plurimum, sin cosas muy torpes y provocativas, assí en lo que se representare como en el modo de representarlo, se pueden y deven admitir como honesto alivio y recreación.

5. Que para assegurar lo dicho, bastará la exacta averiguación que haze el ordinario examinando las comedias, a quien por derecho pertenece verlas y examinarlas antes que se representen, de cuyo zelo y christiandad debe esto fiarse. $Y$ en quanto al modo de representar, que no sea torpe ni provocativo en comedia, entremeses y bayles, se fía, como perteneze a alguno o algunos de los señores juezes de la Real Audiencia que assista para dicho efeto.

6. Que supuesta la verdad de las sobredichas proposiciones, se determina que los muy illustres señores administradores del Hospital desta Ciudad, atenta la necessidad extrema dél y el seguro de su reparo haviendo comedias, puedan con segura consciencia conducir, quan presto puedan, representantes que representen en esta ciudad» ${ }^{43}$

La insospechada publicación de la consulta, encabezado por la rúbrica del propio don Luis Crespí, no pudo llegar en peor momento para él, con su más conocido sermón sobre las comedias recientemente editado. Saliendo al paso para salvaguardar su credibilidad, compondría una apresurada retractación notarial impresa antes de concluir el verano de 1649. Insinuó en ella la discordancia entre el acuerdo adoptado por la junta y la resolución ahora aireada

«No puedo borrar, como desseo, con mi sangre lo que firmé con mi pluma. Quiero hazer con este papel lo que desseó san Agustín con sus retractaciones, enmendando por este camino lo que dicho una vez no pudo revocar... He sentido siempre y predicado que las comedias, como se usan en España, no son lícitas. Y en una junta, que se tuvo en la

${ }^{41}$ R. M. Hornedo, «Teatro e Iglesia en los siglos XVII y XVIII...», p. 328.

${ }^{42}$ M. VILAR Devís, El Hospital General en la Valencia foral moderna..., pp. 282-296.

${ }^{43}$ BUV. Ms. 13, T. GÜELL, Noticias varias..., sp.

Hispania Sacra, LXIII

127, enero-junio 2011, 133-153, ISSN: 0018-215-X 
iglesia del Hospital general sobre la materia, a veinte y seis de agosto, lo dixe públicamente. Después firmé un papel... en el qual se dize que las comedias si no son muy torpes, son lícitas; y que, no siendo ut in plurimum muy torpes y muy provocativas, se pueden y deven admitir, como honesto alivio y recreación. Proposiciones de las quales se infiere que las que no son muy torpes, aunque sean torpes, son lícitas; y aunque aya algunas muy torpes, como no sean las más muy torpes, que esso significa aquel término in plurimum, se deven admitir como honesto alivio y recreación, cosa que está tan lexos de la verdad que sería digno de grave censura el afirmarlo. Y aunque pudiera dezir que nada de esto se resolvió en la junta referida y alegar otras razones que bien entendidas me sirvieran de disculpa, no quiero disculparme, sino retractarme, porque aquella firma mía puede dar ocasión a esta mala inteligencia. Y assí digo que la retracto, la revoco y anulo, y que la verdadera y católica doctrina de todos los santos y doctores es que las comedias en que se mezclan cosas torpes, aunque no sean muy torpes, no son lícitas ni se pueden ni deven admitir como honesto alivio y recreación». ${ }^{44}$

Las excusas del pavorde no impidieron a los responsables del Hospital general seguir adelante con sus planes para devolver el teatro a Valencia. En este sentido, recogerían en el convento de Predicadores una testificación sumaria de varias decenas de religiosos, sacerdotes, nobles, caballeros, ciudadanos y otras gentes para probar que «s·ofèn més a Déu Nostre Señor en pecats de homicidis, robos, pendències, inquietuds de dones casades, viudes honestes e donselles y altres casos inormes en lo tems que no y ha comèdies, per estar divagant moltes persones jóvenes y pasechants, que quant les y ha en la present ciutat». ${ }^{45}$ Los referidos testimonios, más el dictamen positivo de la junta, sirvieron a los administradores del centro para iniciar las pertinentes diligencias en la corte a través de Jacinto Maluenda, alcaide de la casa de la Olivera. ${ }^{46}$

Don Luis Crespí, y por extensión el Oratorio de San Felipe Neri habría de soportar, entretanto, el aluvión de críticas descarnadas provocadas por su retractación pública. Unas de las primeras en hacerse oír fueron las de don Diego Vich. ${ }^{47}$ Último del linaje de su nombre, caballero de la orden de Alcántara y antiguo paje del Rey Prudente durante sus años en la corte, donde alcanzó fama

\footnotetext{
${ }^{44}$ Retractación de la firma del doctor don Luis Crespí de Borja en el papel que anda impresso a favor de las comedias, Valencia, 1649. Este documento quedaría incluido en la segunda edición del sermón atrás citado, aparecida en 1683, también en la capital del Turia, con motivo del recrudecimiento de la polémica sobre las comedias suscitado por la Aprobación que de los dramas de don Pedro Calderón de la Barca hizo fray Manuel de Guerra y Ribera. Aún entonces seguirían lloviendo críticas a Crespí por su escrito, como las atribuidas al singular don Andrés Dávila y Heredia en su Respuesta a la respuesta de una consulta sobre si son lícitas las comedias que se usan en España, donde impugnaría con acidez las razones de Crespí. E. CotARElo Mori, Bibliografía de las controversias..., pp. 196 y ss. Los originales de todos estos impresos pueden consultarse en la Biblioteca Universitaria de Valencia.

${ }^{45}$ L. LAMARCA, El teatro en Valencia..., p. 65.

${ }^{46}$ La embajada en cuestión no sería formalmente aprobada hasta el 27 de mayo de 1650. H. MÉRIMÉE, El arte dramático..., vol. II, p. 628.

47 V. Ximeno, Escritores del reyno de Valencia..., vol. II, pp. 360-361.
} 
de erudición por su pasión hacia la Historia y las Matemáticas, el anciano señor de Llaurí articuló en su Breve discurso a favor de las comedias y su representación una apasionada defensa de estas piezas consentidas por obispos y aún la Inquisición, según su autor, e imprescindibles para el sostenimiento del Hospital general, mal que pesara a los crispianos, a quienes señalaba por sus sermones y acciones como urdidores de una campaña antiteatral avidos de nuevas vocaciones y fieles que les hicieran mayor hueco entre las religiones valencianas,

«Bien creo que singularizarse en las conversaciones y en el púlpito en esta materia es celo santo. Pero también tengo licencia, supuesta la fagilidad humana, de temer no se entremeta en ello alguna sutileza diabólica, porque embarazado y entretenido el predicador en reprehender lo que en sí no es culpa mortal, se descuide de lo que lo es de todos cuatro costados... y persuadirse que la privación de comedias ha de ser medio proporcionado para atraer inmediatamente cachibeatos al Oratorio y al silicio y diciplina es dictamen por lo violento, peligroso, y más en los ánimos valencianos. Y esto de la dirección de las almas, ya se sabe que requiere más la maña que la fuerza...».48

A invectivas como éstas, aun sin citar nombres, haría referencia el más reputado biógrafo de nuestro Crespí, fray Tomás de la Resurrección Saboya; a ellas y alguna otra. Escuchémosle

«De esta retractación que hizo el venerable don Luis procedió el murmurarle desenfrenadamente. De aquí se originó el decir muchos desdoros sin fundamento a sus espaldas, hablando cada uno de los injustos murmuradores no conforme al dictamen de la razón, sino conforme a la irritación de su depravado apetito, sin considerar que este evangélico predicador no interesaba en la impugnación de las comedias riquezas para su codicia, premios para su ambición ni aplausos para su vanidad, sino solamente cortar el arcaduz del veneno que por el ejercicio liviano de las comedias se entraba hasta el centro de muchas almas. Pasó la indignación de la lengua al furor de la pluma, y cierta persona de aquellas que en el vulgo tienen la estrella de bien vistas por lo florido de sus razones y por lo airoso de sus dichos, escrivió un soneto contra el siervo de Dios, en el cuál le hirió todo lo que pudo. Mas, ¿qué herida, qué veneno puede ofender o qué indignación agraviar en donde por la mucha virtud no hay capacidad para la herida, para la llaga ni para el golpe?. Leyó casi toda la ciudad, y toda casi con horror y enojo, lo que contenía aquella infamatoria poesía, que inventaba, movida de impulso diabólico, falsedades que no cabían en tan candidísimo pecho, ignominias contra la luz de su doctrina, lunares fingidos en sus modestíssimas costumbres y, lo que más pudiera irritar al siervo del Señor, libertades y oprobios contra la sagrada congregación de San Felipe Neri...».49

${ }^{48} \mathrm{El}$ Breve discurso de don Diego Vich, publicado en Valencia en 1650, volvió a ser editado a finales del siglo XIX por J. E. Serrano Morales, y recogido más tarde por E. COTARELo Mori, Bibliografía de las controversias..., pp. 587-591.

${ }^{49}$ F. ResurRección SABOya, Vida del venerable y apostólico prelado..., p. 238.

Hispania Sacra, LXIII

127, enero-junio 2011, 133-153, ISSN: 0018-215-X 
La «cierta persona» insinuada por el padre Saboya era mosén Pedro Jacinto Morlá, beneficiado de la parroquia de San Martín de Valencia y escritor burlesco que vivía alternando los rezos con la composición de versos en las diferentes justas y academias reunidas en la capital; ${ }^{50}$ y su «soneto», en realidad un romance, la Sátira en defensa de las comedias compuesto contra el impugnador de las mismas. ${ }^{51}$ Las razones que para afilar su pluma tuvo este clérigo, empedernido espectador teatral donde los hubiere y admirador convicto y confeso de Lope de Vega, desbordarían en la presente ocasión lo estrictamente literario, revelándole como ariete de los eclesiásticos contrarios a compartir protagonismo e ingresos con la congregación del Oratorio.

\section{LA SÁTYRA EN DEFENSA DE LAS COMEDIAS DE MOSÉN MORLÁ}

Desde tiempo casi inmemorial, el clero valenciano había acostumbrado a su feligresía a toda suerte de pugnas fratricidas, cuyas heridas apenas tenían tiempo de restañarse..$^{52}$ Seculares frente a regulares, canónigos frente a dignidades, franciscanos frente a dominicos o dominicos frente a jesuitas, serían sólo algunas de las infinitas combinaciones de tales trifulcas. La última y más sonada de ellas, con motivo de la controvertida santidad del pare Simó y sus implicaciones en el debate sobre la Inmaculada Concepción de la Virgen María, todavía continuaba enfrentando a los sectores en lid, básicamente la religiones mendicantes opuestas al nuevo santo, por un lado, y del otro la clerecía parroquial y catedralicia, apoyada por la Compañía de Jesús, decididas simonistas ambas. ${ }^{53}$ En este contexto, la discutida licitud de las comedias no haría sino dar nuevos motivos para la discordia.

\footnotetext{
${ }^{50}$ A. FERRANDO, «Un poeta inèdit del Barroc valencià: Pere Jacint Morlá», en C. ROMERO y R. ARQUÉs, Cultura catalana tra l'Umanesimo e il Barroco, Padova, 1994, pp. 295-319, y «L'obra literària de Pere Jacint Morlà (ca. 1600-ca. 1656)», en Escriptors valencians de l'edat moderna, Valencia, 2004,pp. 161-176. A cargo del mismo autor corrió la edición e introducción de las Poesies i col-loquis de mosén Morlá, publicadas en Valencia en 1995.

${ }^{51}$ Datada en 1649, se conserva en el manuscrito número 13 de la Biblioteca Universitaria arriba citado. Una aproximación a ésta, desde el punto de vista literario exclusivamente, en J. MouYEN, «Un témoignage valencien de la controverse éthique sur la licité du théâtre: la Sátira en defensa de las comedias de mosén Pedro Jacinto Morlá», Bulletin hispanique, 96-2 (1994), pp. 301-333; A. MADRoÑal DuRán, «La Sátira en defensa de las comedias de Pedro Jacinto Morlá (1649), una apología de Lope y su teatro», Anuario Lope de Vega, 9 (2003), pp. 275-328 y «Teatro breve de autores bilingües: el caso de Pedro Jacinto Morlá», en Actas del Congreso El Siglo de Oro en el nuevo milenio, 2005, vol. II, pp. 1089-1108.

52 R. I. BuRns, El reino de Valencia en el siglo XIII (Iglesia y sociedad), Valencia, 1982, 2 vols.

${ }^{53}$ E. Callado Estela, Devoción popular y convulsión social en la Valencia del Seiscientos, Valencia, 2000, y Sin pecado concebida. Valencia y la Inmaculada Concepción en el siglo XVII (En prensa).
} 
Según el cronista mosén Gaspar Escolano, tan popular espectáculo contaba en Valencia con el respaldo de inquisidores, curas, frailes y otros muchos eclesiásticos «que no juzgaban indecoroso ni en pugna con su ministerio la asistencia al teatro, donde encontraban un pasatiempo decente». ${ }^{44}$ Las cifras confirman que el porcentaje de clérigos que acudían con asiduidad al corral de la Olivera era muy elevado, disponiendo en su mayoría de silla reservada para los días de estreno. ${ }^{55} \mathrm{El}$ mismo convento de Predicadores había albergado entre sus muros alguna representación, en abierta discrepancia con su antagonista en tantas otras ocasiones, la Compañía de Jesús, que junto al Oratorio reprobaban las comedias. En el caso concreto que nos ocupa, no fue necesario que los religiosos de santo Domingo respondieran a los papeles del filipense proignaciano don Luis Crespí de Borja, por cuanto mosén Pedro Jacinto Morlá, en un alarde de filodominicanismo, lo haría por ellos.

Efectivamente, a lo largo de su vida el beneficiado de San Martín anduvo siempre vinculado a la orden blanquinegra, a sus celebraciones y santos -a los que escribió más de una composición poética, como el Romanç a sant Vicent Ferrer con motivo de cierta efeméride vicentina- y por supuesto a sus religiosos. Entre estos últimos tuvo íntimos amigos, contándose por tales el arzobispo de Valencia fray Isidoro Aliaga, el cronista fray Francisco Gavaldá, ${ }^{6}$ y curiosamente, el Provincial de Aragón fray Francisco Crespí. Además de devociones y amistades, el clérigo, «muy afecto nuestro» según las crónicas de santo Domingo, compartía con los dominicos la doctrina tomista en materia teatral. No es casual pues que los mismos historiadores de la orden anotaran, al respecto del revuelo provocado por los escritos de don Luis, que su deudo mosén Morlá «tomó la demanda contra dicho sermón defendiendo a los de sentir contrario, y entre éstos a los dominicos». ${ }^{57} \mathrm{Y}$ qué mejor modo que refutar en verso, con su ingeniosa Sátyra, los conocidos argumentos del pavorde, apelando desde la primera estrofa al Aquinate, a quien ya había dedicado uno de sus romances en acción de gracias por el fin de la última peste y a cuya autoridad volvía ahora a encomendarse,

\author{
«Porque Thomás el Angélico, \\ que assí la Iglesia le llama, \\ como el sol, el solo puede \\ en tu doctrina ofuscada \\ darte luz para que veas
}

\footnotetext{
${ }^{54} \mathrm{G}$. Escolano, Década primera de la Historia de la insigne y coronada ciudad y reyno de Valencia, Valencia, 1610, lib. III, p. 825. La cita la reproduce M. VILAR Devís, El Hospital General en la Valencia foral moderna..., p. 401.

55 J. MOUYEN «El corral de la Olivera de Valencia en 1678 y 1682: tentativa de definición sociológica de su público», en Homenatge al doctor Sebastià Garcia Martínez, Valencia, 1988, vol. II, p. 109.

${ }_{56}$ V. XIMENo, Escritores del reyno de Valencia...,vol. II, pp. 98-99.

${ }^{57}$ BUV. Ms. 13, T. GÜELL, Noticias varias..., sp.
} 


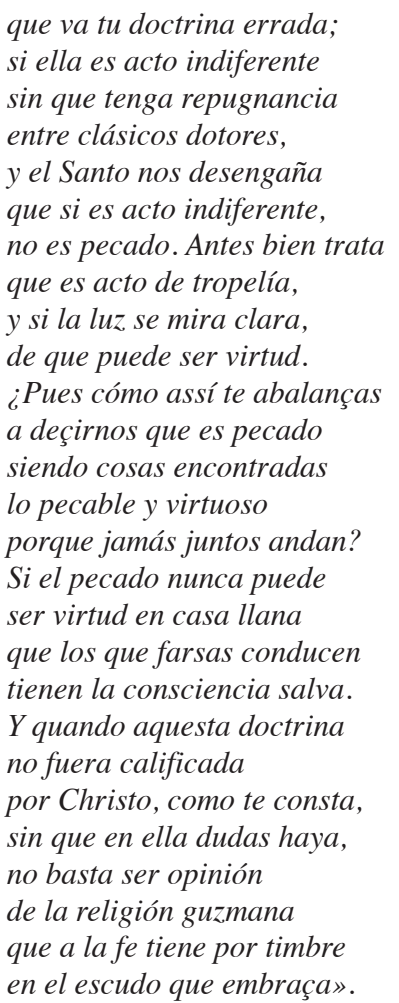

De la bondad de estos dramas no cabía la menor duda al beneficiado de San Martín. Luego vetos y censuras estaban fuera de lugar cuando de ellos se trataba, conforme habían sostenido antes que él autoridades en la materia, ¿o eran tales «personas desalmadas, que no saben Theología y en las letras no te ygualan?», espetaba al oratoriano. Aunque en contadísimas ocasiones pudiera justificarse el recurso a la prohibición, los beneficios obtenidos para los Hospitales, en Valencia y toda la Monarquía, merecían por sí solos tolerar un espectáculo en general aplaudido por la Iglesia, a la que tanto había servido en sus fines apostólicos. Con grandes cómicos y mejores cristianos, de la categoría de San Ginés «el pío», la Baltasara, «por mucha virtud está tenida por santa» o Josefa Vaca, que «quando al theatro salia, su pie no vieron las tablas pues tuvo en sí tal recato que aún de sí se recatava», y dramaturgos laureados por la Santa Sede, como el gran Lope, sacerdote, hombre de bien y autor de obras piadosas por todos conocidas, Jerusalén conquistada, Los pastores de Belén y Rimas sacras, etcétera, que "quiçás han convertyido más gente que tú por plaças con actos de contrición y aquella alma condenada...». 
A qué entonces, se preguntaba mosén Pedro Jacinto, tan desmesuradas andanadas por parte de un ministro de la Iglesia, cuyo genio más le había podido que el tiento exigido por su condición pastoral

\author{
«Mayoral del Oratorio, \\ Dios ponga tiento en tu caña, \\ pues que ya de tu doctrina \\ las cañas se buelven lanzas. \\ ¿Qué te han hecho las comedias, \\ los comediantes, las farsas, \\ los bayles, los entremeses, \\ los toros y las farsantas? \\ Dilo, señor, por tu vida, \\ que un sermón diste a la estampa \\ que si buen zelo le viste \\ mucha imprudencia le calça»
}

Las opiniones, no obstante, eran libres, reconocía el clérigo. Tan libres que Crespí había tenido ocasión de exponer su parecer ante la junta de sabios reunida en la capilla del Hospital general antes de aprobarse una resolución propicia a las comedias que mereció veinticinco votos; "y uno tan sólo entre todos fue el que siguió tus pissadas», en referencia al padre Jerónimo Vilar, quien se negó a firmarlo por razones ya conocidas. No así don Luis, cuyos reparos -motivados quizá por la lamentable situación económica del principal centro hospitalario de la capital- le habían hecho vacilar durante algunas horas. Sólo después de acudir al convento de Predicadores para entrevistarse en privado con su hermano fray Francisco, que "aunque te estima y ama es tan cabal, tan entero, que a su obligación no faltó», tomó el documento para rubricarlo de su mano, sin que nadie le obligara. Ahí habría quedado el asunto, siempre según el beneficiado de San Martín, de no haber intervenido los oratorianos, contrarios a la restauración de las representaciones dramáticas por las repercusiones que ello podría acarrear a su floreciente comunidad

\footnotetext{
«Dícenme que aquella noche

fueron notables tus ansias

de ver que los capachicos

a grandes vozes gritavan

¿Padre nuestro, que has lastimado,

que te han coxido la trampa,

porque estas proposiciones

van en malicia fundadas,

que son contra tu sermón,

y nos han de dar matraca

quando en aqueste Oratorio

notemos tal alaja!.

Remédialo, por tu vida,

busca modos,busca traças,
}

Hispania Sacra, LXIII

127, enero-junio 2011, 133-153, ISSN: 0018-215-X 


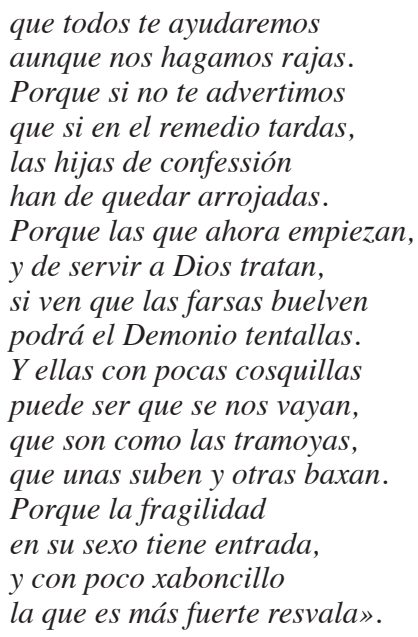

Por eso habría tratado el pavorde al día siguiente, por medio de otro de sus hermanos, don Juan Crespí, lugarteniente general de la orden de Montesa, ${ }^{58}$ que los administradores borraran su nombre de la sentencia, a lo que no accedieron, que sí a algunas matizaciones del texto condicionadas al cese inmediato de sus manifestaciones públicas contrarias a las comedias. De nuevo, el Oratorio habría obligado a don Luis a desdecirse, esta vez a través de la retractación notarial que en tan mal lugar le había dejado. Merecía cuanto le había ocurrido por andarse «entre lobos» como estos sacerdotes, amamantados en el odio hacia la infernal invención que decían ser el teatro, cuando quien más y quien menos, incluidos ellos mismos, se había deleitado como espectadores
«Que las comedias vinieron del Infierno y que las casas son palacios del Demonio yo lo tengo por patraña. Que de esso se seguiría que aquellos que ven la farsa están dentro del Infierno y no es possible que salgan. Que lo que dicen de Orfeo, que entró con una guitarra en el Infierno y sacó su muger de entre las llamas, es historia fabulosa;

${ }^{58}$ Los interesados en este tercer Crespí pueden recurrir a J. BORJA Y ARÁNDIGA, Breve resolución de todas las cosas generales y particulares de la orden y cavallería de Montesa. Ed. F. ANDRÉs RoBRES y J. CERDÁ Ballester, Valencia, 2004. 


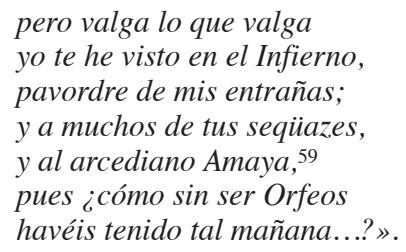

Cómo creer a estas gentes, entonces, al asegurar que la erradicación de las comedias multiplicaría la piedad de los valencianos, y de la propia congregación filipense, en forma de limosnas al Hospital. ¿Acaso había ocurrido así durante los últimos tiempos sin representaciones teatrales?
«Aunque algunos asseguían que el día que esté quitada la comedia el Hospital tendría más medras y mandas, son cuentos de calahinos que dexar fuera bovada, lo cierto por lo dudoso, callen barbas y hablen cartas.
Pues en tres años y más que sin comedias se halla, de vuestras mandas no tiene tan solamente una blanca».

Al contrario de los denostados poetas -mosén Morlá, sin ir más lejos-60 tampoco el Oratorio había arrimado el hombro en época de peste, demostrando una vez más su catadura,
«Los poetas empestados, mira en la peste passada, que ninguno dio tributo de quantos son a la Parca, assistiendo a la ciudad sin salir de sus murallas, acción que las mussas quedan con ella calificadas.

${ }^{59}$ Se refiere mosén Morlá al catedrático de Teología, predicador de talento y arcediano de la catedral de Segorbe, Jacinto de Amaya. Aunque no perteneció al Oratorio, mantuvo vínculos estrechos con algunos de sus miembros. Fue también fundador de la Escuela de Cristo, confesor de monjas y amigo de beatas. J. RodríGuEZ, Biblioteca Valentina, Valencia, 1747, pp. 231-232.

${ }^{60}$ Es el citado padre Gavaldá quien así lo sostiene en su Memoria de los sucessos particulares de Valencia y su reino en los años mil seiscientos quarenta y siete y quarenta y ocho, tiempo de peste, publicada en la misma ciudad el año 1651 y cuyas páginas iniciales incluirían una composición poética de mosén Morlá dedicada al propio cronista blanquinegro.

Hispania Sacra, LXIII

127, enero-junio 2011, 133-153, ISSN: 0018-215-X 


\begin{abstract}
Muchos de los que te siguen, y que contigo descansan, temerosos de la muerte $y$ de su fatal guadaña, por no seguir la opinión de fray Luis de Granada, dexaron la charidad y buscaron la esperanza. Que aunque tienen mucha fe, charidad bien ordenada, quando por ellos empieza también por ellos acaba».
\end{abstract}

Mejor sería para todos preocuparse por la salvación de la grey, acechada por verdaderos pecados como la delincuencia o la prostitución, la alcahuetería o la usura, infinitamente peores que la asistencia a unas cuantas farsas, inocentes en su mayoría. Contra tales lacras debería predicar Crespí, quien, puestos a pedir, podía dedicarse a limpiar también su casa de aquellos sacerdotes indignos del hábito que vestían
«De aquestos engañamundo
quisiera que predicaras,
levanta la voz con ellos
pues en todo se levantan.
Enseña tu gran valor
$y$ hechen de ver que los cardas
y sepan que conocemos
que son hombres de la carda».

Temía mosén Pedro Jacinto Morlá, confesaba para concluir su demoledora Sátyra, que el pavorde continuara ensordecido por los aplausos de quienes sólo buscaban en él llegarse hasta el Consejo de Aragón, cuya vicecancillería, distribuidora de empleos y prebendas, a punto estaba de ser conquistada por su todopoderoso hermano mayor don Cristóbal Crespí, que después de desempeñar diferentes cargos en la judicatura valenciana, desde la Bailía y la Real Audiencia, había pasado a la corte para velar desde aquella privilegiada atalaya por la carrera de todos los suyos... ${ }^{61}$

\footnotetext{
${ }^{61}$ J. ARrieta Alberdi, El Consejo Supremo de Aragón (1494-1707), Zaragoza, 1994, y «Cristóbal Crespí y su generación ante los fueros y las cortes», en R. FERRERo Micó y L. Guía Marín (eds.), Corts i parlaments de la Corona d'Aragó. Unes institucions emblemàtiques en una monarquia composta, Valencia, 2008, pp. 43-68. Obra colectiva esta última en la que también se incluye otra interesantísima aproximación al personaje, en este caso de V. Pons Alós, «Aportación a la historia familiar de tres juristas valencianos: Cristóbal Crespí de Valldaura, Llorenç Mateu y Sanz y Josep Llop», pp. 19-42.
} 
Las acusaciones vertidas por el beneficiado de San Martín iban a costarle muy caras, por cuanto darían con sus huesos en la cárcel por orden del lugarteniente general del reino, el conde de Oropesa. No bastaron los barrotes para amilanar su ingenio, escribiendo durante el cautiverio nuevas mofas sobre su carcelero el virrey o el pugilato entre oratorianos y frailes

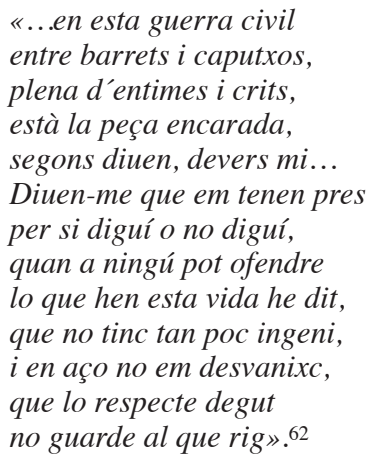

De creer al padre Saboya, el reo no recuperaría la libertad sino gracias a la intercesión del principal agraviado por sus injurias, que

«...doliéndose de su enemigo a quien tenía preso con más fuertes vínculos en lo íntimo de su corazón, se fue al virrey y le pidió, con tanto encarecimiento y con súplicas tan urgentes, la libertad del encarcelado, que por no desconsolarle aquel príncipe, hubo de condescender con sus santos ruegos, y le mandó sacar de la cárcel con mucha brevedad. Salió el ofensor de la prisión, y salió también de las cadenas de su error, y con gran rendimiento fue a pedir perdón al ofendido». ${ }^{63}$

No habría que descartar, aún así, que el responsable último tanto de la excarcelación como de la reconciliación fuera el Provincial dominicano fray Francisco Crespí, en su doble condición de amigo de mosén Morlá y hermano de don Luis. En cualquier caso, mientras el primero se reincorporaba a su beneficio en la parroquia de San Martín, desde el que seguiría escribiendo versos hasta el día de su muerte, el segundo hubo de guardar silencio durante algún tiempo en la congregación filipense, donde le sorprendió la reanudación de las representaciones teatrales en Valencia por obra y gracia de Felipe IV, dejándose temporalmente sin argumentos a los detractores de las comedias. En tan embarazosa

\footnotetext{
${ }^{62} \mathrm{El}$ fragmento corresponde al Romanç que féu quan la seua presó. Las referencias a las cuitas clericales serían una constante en algunas otras de sus composiciones poéticas. Aquella, sin ir más lejos, iniciada con el verso Portà Medina en la Nau volvería a referirse a «los canonges en roquets, / los capellans en barrets/ i los frares en caputxos». P. J. Morlá, Poesies i col-loquis..., pp. 78, 80 y 84.

${ }^{63}$ T. ResurRección SABoya, Vida del venerable y apostólico prelado..., p. 165.
} 
tesitura, fue su otro hermano don Cristóbal quien, desde el Consejo de Aragón, y a la par que facilitaba la consolidación definitiva del Oratorio en tierras del Turia, durante el pontificado del nuevo arzobispo fray Pedro de Urbina, un fraile franciscano, ${ }^{64}$ le ofrecería una honrosa salida a comienzos de 1651 mediante su promoción al episcopado, en virtud de la vacante producida en la diócesis de Orihuela por la muerte de su titular, don Juan de Orta y Moreno. ${ }^{65}$

Unos años tan sólo recaló allí don Luis Crespí de Borja, catapultado de nuevo a más altos destinos bajo el patrocinio del todopoderoso vicecanciller. Se trataría esta vez de la embajada extraordinaria ante la Santa Sede para solicitar la definición de la Inmaculada Concepción de la Virgen, cuyo éxito en 1661 hizo olvidar su participación en la polémica sobre el teatro, que con nuevos protagonistas todavía daría mucho que hablar en las décadas posteriores.

64 Ibidem, pp. 106 y ss. Sobre este prelado valentino, remitimos a J. TEIXIDOR, Episcopologio de Valencia (1092-1773). Introducción y transcripción de A. Esponera Cerdán, Valencia, 1998, pp. 172192.

65 C. Eubel, Hierarchia catholica Medii et Recentioris Aevi. IV (1592-1667), Monasterii, 1935, p. 265. Para esta nueva etapa en la vida de don Luis Crespí, véase G. VIDAL TuR, Un obispado español: el de Orihuela-Alicante..., vol. I, pp. 226 y ss. 